\title{
1. Introduction, the UK's relationship to the EU, the aim of this book and policy conclusions
}

The central theme of this book is that the European Union has developed economic policies in trade and regulation that do not conform to the liberal model of free markets under the rule of law. Instead they are protectionist and interventionist because of the pressures of political preferences and vested interests. The European Union Treaties proclaim with great clarity that the EU is a political project whose ultimate aim is complete political union and whose journey is guided by the process of 'ever-closer union'. While UK politicians have from time to time thought that it was a project for a single market moving towards full competition internally and full free trade internationally, this has not turned out to be correct. Instead the EU has introduced extensive social regulation, has attempted to integrate legal processes across borders, has intervened heavily in fiscal decisions of euro-zone governments, has pursued aggressive policies on climate change without attention to cost effectiveness, and has done much else - overall going well beyond and often in contradiction to that free market programme.

As part of these efforts the EU has worked untiringly to create political allies in all EU states within their business, personal and regional structures - in no country more so than the UK. Thus the business beneficiaries of EU protectionism are vocal in their support of the EU, whether in agriculture, manufacturing or services (such as the City). Regions in receipt of EU subsidies are in favour of the EU because of this perceived largesse, even though they involve a usual cost to the UK Treasury equal to 87 per cent of the EU payout since the 'UK rebate' falls by 67 per cent and matching funds of 20 per cent are typically required. At a personal level households receive regular information on how the EU has improved their tourism opportunities, their environment and their general interchange with other European peoples; they are told frequently by pro-EU politicians how they would face uncertainties and loss of jobs outside the EU. As a result the main organs of opinion favour staying in the EU, and the main business groups, regional lobbies and citizen interest groups 
also lobby for this. It is thus easy to argue that the case for staying in is a 'business' one even though a moment's reflection reminds us that business opinion is not the same thing as the economic interests of UK citizens.

The viewpoint of this book is that of the economist. The book reviews the costs and benefits to UK citizens of the EU, much as the Manchester liberals Cobden and Bright reviewed the costs and benefits of the Corn Laws in the early nineteenth century; then too a large and powerful business (agricultural) lobby opposed repeal.

This book focuses mainly on the role of trade, the central function of the EU; while this is not we think the major source of costs to the UK, it has been widely misunderstood as an advantage of EU membership because it gives us 'access' to the EU market and to markets with which the EU negotiates trade agreements. This is a fallacy: the book is principally devoted to explaining that this is the case because international trade is about the price at which you can sell your exports and buy your imports. We then go on to explain how the EU is a customs union devoted to raising the prices at which we can buy imports and selectively raising the prices of our exports and that this protectionist strategy, like virtually all such strategies, reduces our welfare.

Because there are so many other facets of EU membership we also devote space to these. We consider regulation to be an obvious source of intrusion that many have seen is costly. With the euro-zone bringing about a surge in new controls from Brussels and reminding us that 'ever-closer union' must imply that the UK eventually joins the euro, we have added some material on the effects of this. Since the euro-zone crisis it has become apparent that 'bail-out' is a central feature of the euro-zone and indeed of the EU, which has forced countries outside the euro such as ourselves to help out too; we have updated our review of the possibilities of the UK being involved in transfers to the rest of the EU in the future. A further topic that we have devoted some space to is immigration, now a central part of the UK political debate and closely linked to the free entry of people from the rest of the EU. Finally, much concern has been expressed about what the world trading environment would be like for a free trading UK outside the EU; we have added sections looking carefully at this. Other than these central issues, we have generally updated the factual background and the review of other work in this edition.

The book is organized into two main parts. The first is devoted to summarizing the economic issues involved in EU membership. Some of these are not to do with trade: regulation, the euro, possible bail-out demands, and of course the basic membership fees. Much has been written on these issues and we attempt to build on this and give our own summary account of costs and benefits, using models we have developed that give us some 
ability to calculate these. Then we consider trade and the ways in which our EU membership diverts us from free trade to our ultimate cost. Many, as pointed out above, believe that at least in this respect the EU is a fine institution, contributing to opening up trade barriers around the world. Thus some have argued we should leave the EU, 'except in trade'. But this is a quite wrong assessment and was originally the cause for writing this book. We devote the fourth chapter to determining a broad estimate of the costs the EU's wide protectionist agenda has imposed on UK (and indeed EU) citizens.

In the second part of the book we devote three full chapters to the full story of what the EU has done in the areas of trade in agriculture, manufacturing and services. These chapters set out in considerable detail both the facts and available analyses of how trade and trade protection has developed, especially in the EU, and how much this distorts trading patterns around the world.

The rest of this chapter is effectively both an introduction to the book and an extended 'executive summary' of it.

\section{THE AIM OF 'BREXIT' - OR BETTER 'BRESET'}

'Brexit', as it is popularly known, is therefore the topic of this book. But this conjures up pictures of bad-tempered 'departure' and 'divorce' followed by either a poor relationship with the EU or none at all. However, this is not what we believe to be the alternative to continuing in the current EU. Let us accept for a start that 'renegotiation' of the current EU Treaties (as summed up in the latest Lisbon Treaty) is not a realistic idea since the changes the UK would require would mean a rewriting of many treaty areas and these changes in turn would need unanimous agreement from all member states of the EU. While no one can prevent politicians from attempting such a renegotiation of the Lisbon Treaty, its prospect of success is vanishingly small. What we have in mind in this book is something else - a new treaty between the UK and the EU which for both sides would embed what is good and would eliminate the current sources of endless mutual discontent.

As we will see in detail in the following pages, the UK suffers from excessive direct intervention in UK economic and political affairs from the EU. Most of all, it suffers from the uncertainty of what 'ever-closer union' might bring in the way of additional interventions. In the costs we enumerate, the biggest potential costs lie ahead, in the form of possible measures implied by current EU aims. Thus 'opt-outs', such as that we have currently from joining the euro, cannot be considered safe in this 
longer-term perspective. We already saw how one such opt-out, from the Social Chapter, was ceded by the Blair Labour Government, no doubt as part of some imagined trade-off with benefits to be obtained from Brussels or merely as a way of ushering in 'socialism by the back door'. This event illustrates how easily the UK could be sucked into more and more EU intervention by remaining a member of the EU under the present treaty; whether it happens by EU pressure or by willing complicity on the part of UK politicians whose agenda of the moment it might suit (but who may later regret the cumulative effect of their actions), there is a ratchet effect at work in this EU relationship as defined in the Lisbon Treaty. That treaty never surrenders any powers the EU has acquired (the 'acquis communautaire') and hence any surrender from the UK side accumulates its losses of control; each time we surrender, our politicians say 'ah well, it is easier to give in and to stay in than to try to change the beast' and thus it is we find ourselves some forty years since entry into 'the Common Market' in an all-pervading 'European Union' relationship we never seriously dreamt of, let alone intended.

What is needed instead is a new bilateral treaty which defines a limited relationship, limited in its current and future scope to definite areas of mutual benefit - let us call it a 'resetting' of our relationship with the EU or 'Breset'. As we will see, this will include cooperation in trade and regulation, preserving the best of what we now have of these, while jettisoning the excessive protection and over-regulation (notably in the labour market) and the threats of their future extension which we abhor. Being 'out' of the EU will then imply a far more flexible relationship with the EU in which good shared regulation and trade relationships will be preserved. The fears expressed by many about being 'out' will be seen to be groundless in this perspective.

We will develop the details of this new relationship in what follows. But here we sketch the basic idea. At the core of our relationship with the rest of the EU lies the Single Market, which is intended to prevent country regulation from acting as a trade barrier, and free trade access throughout the EU's geographical area. Though this does not extend much to services, our key UK sector, it greatly affects our manufacturing industry. As we will see later, the problem with this lies in its high level of protectionism through the EU's Customs Union policies which keep out or restrict imports of non-EU products: it is not only in its well-known Common Agricultural Policy that the EU is protectionist. Somehow therefore we need to extricate ourselves as a major trading nation from the EU's protectionism while preserving the benefits of the Single Market and free trade within the EU. This can be done. In the first place, where the UK feels that product regulations are helpful to industrial integration, they can be 
left alone and protected in a new treaty. Secondly, where trade barriers are concerned, it is possible for the UK to maintain free bilateral trade with the EU, while also removing trade barriers against other countries, in industries where there is a high degree of integration between the UK and the rest of the EU. This is possible because the way that the EU mainly levies its protection is via trade agreements on access and pricing; so effectively in these highly integrated industries (such as the volume car industry) the UK would continue to price its products in the rest of the EU as it now does. Even though imported products from the rest of the world would drive UK prices down to world levels, these lower prices would not filter through into the rest of the EU.

The idea of a new UK-EU treaty would therefore be to preserve the existing relationships that achieve virtuous integration. But at the same time the UK would not implement regulations that damaged the economy as a whole. The idea that trade is held up by differences in regulation that have a distant relationship to the trading industry (such as general labour market regulations) is not accepted in WTO judgements or in the theory of trade; differences between countries' institutions are a valid source of cost differences, and contribute to competition. So UK regulations will in general be based on UK judgements of cost-benefit. Nor would the UK adhere to the single market in labour, rather exerting normal immigration controls based essentially on skill points, as in the US 'green card' system. It would withdraw sine die from any potential involvement in the euro or in trans-EU bail-out arrangements. It would agree to mutually advantageous extradition arrangements but not to any pooling of justice systems. It would cooperate with the EU foreign office just as it does with the US State Department. It would join forces with the EU in general talks on trade, such as the one currently going on with the US, where all sides stand to benefit from agreement.

In short the UK would once again become a sovereign country, friendly with its large neighbour just as it is friendly with countries such as the US, Canada and Australia, and it would agree to close trading and regulatory relationships with the EU as needed for mutual benefit. It is wrong to suggest that such a new treaty cannot be achieved because of the ill-will generated by our demands, though of course it is possible that negotiations for a new treaty would break down, at least for a time. In this book we do our costing on the basis of breakdown and we show that it is worth the UK's while to leave even on this basis; essentially leaving without any new UK-EU treaty would be to adopt a role as a free trading nation in the WTO community, with all our other existing political relationships such as NATO, the OECD and the IMF, and there is absolutely no problem about such a role, as we explain in detail below. But since there is mutual 
gain to be had, relative to breakdown, in both sides reaching a new treaty, it is illogical to suggest it will not be achieved - just as it has been achieved between the EU and both Norway and Switzerland. Once all sides realize that departure is going to happen anyway, all bluffing and threats will be removed and realism will produce discussions on a new treaty. Usually countries, like people, in the end do what is in their interests.

\section{RECENT DEVELOPMENTS: THE EURO-ZONE CRISIS}

The euro-zone crisis is likely to continue for a number of years, with the European Central Bank (ECB) acting as a backstop until agreement is reached on a new institutional structure sufficiently reassuring to Northern Europe that its transfers to Southern Europe will have a good chance of being repaid. The UK's exclusion from the euro has meant that it is neither vulnerable to the panic that has engulfed Southern sovereign bonds nor in direct line to make transfers to the crisis-stricken South.

The institutional framework now being developed implies a high degree of monitoring and intervention by creditor countries of debtor countries within the euro-zone. There will be controls on bank behaviour, targets for governments, and new financial taxes. While in principle this will take place within the euro-zone, there will be pressure to extend it to all EU countries on the grounds that other EU members could 'undercut' eurozone arrangements. The UK will be seen as an offshore competitor with banks, businesses and governments that, being in the euro-zone, are burdened with these controls and regulations. Such competition will be argued to be unfair under the Single Market, for which Qualified Majority Voting applies. It would be easy to extend these things to the UK by majority vote.

Furthermore, the pressures for protection will increase in order to produce as much euro-zone growth as possible, for best prospects of debt repayment. Serious recessions for long periods such as the euro-zone has been undergoing make such pressures intense. The UK suffers at present from the degree of protection for the EU as a whole. This protection will probably increase; even within the EU covert protection against non-euro countries could occur.

At best, the euro-zone will be obsessed with the euro crisis for the coming decade, stalling any progress in liberalizing markets and in increasing competition, things that could have lessened the costs of membership to the UK. This tendency for the euro to strengthen the drive towards excessive regulation as a way of bolstering the single currency was something widely foreseen at the start of the euro. But the crisis is likely to make this much stronger. 
Table 1.1 A survey of costs from EU membership

\begin{tabular}{ll}
\hline & $(\%$ of GDP $)$ \\
\hline Net UK contribution & 0.5 \\
Costs of Common Agricultural Policy and of EU & 4.0 \\
protection of manufacturing & \\
Regulations & $6-25$ \\
Bail-out transfers & $2-9$ \\
Effects of EU regulations on growth to 2035 & 0.5 p.a. \\
Effect of joining the euro on economic volatility & Doubling of volatility \\
\hline
\end{tabular}

Sources: See discussion in later chapters.

For the UK this prospect is extremely damaging. Even without any change in the status quo the economic costs to the UK of the EU are substantial: Table 1.1 summarizes the estimates we make in the rest of this book; we have reviewed our estimates in the first edition in the light of more upto-date information since. The main change has been the rise of trade with China, which has led to a further wave of protectionism, at the same time as protectionism against older competitors such as South Korea has diminished. Meanwhile EU-inspired social intervention has continued to make inroads into UK life, the latest one being widespread rights for temporary workers. With the changes the euro crisis threatens, these costs have increased towards the upper end of the possible spectrum identified in the table. Recent work has also identified possible effects on growth, while we include also the effects of eventual joining of the euro on the economy's business cycle volatility.

A contrary and popular argument for the benefits of the EU to the UK revolves around Foreign Direct Investment (FDI). However, this argument is entirely fallacious. FDI brings benefits because of technological spillovers from foreign firms, which raise productivity. The UK economy's productivity is likely to be maximized when comparative advantage is allowed its fullest rein, that is, outside the EU, under free trade. If this structure implies that industries operating in the UK are more efficient, then less FDI will be required. But this will reflect the fact that the UK is more productive, not less.

Another argument is that leaving the EU would imply costs of 1-3 per cent of GDP due to the imposition of the EU's Common Tariff on the UK (see Ottaviano et al., 2014). This is to be compared with our calculated gain of around 4 per cent of GDP.

As we noted above, we would in practice aim for a new treaty which would preserve the helpful aspects of our trade relationships, notably 
good common regulation and bilateral free trade. Thus the calculations of Ottaviano et al., which come up with a net loss of UK welfare from leaving the EU leave out two important elements:

They do not factor in the effect of moving to free trade with the rest of the world (ROW) from existing EU protective measures. Since on our calculation the EU levies tariff-equivalents on the rest of the world of about 10 per cent, this omission would generate large negative effects if included in their calculation. They appear to assume that the UK would levy the same tariff-equivalents on the rest of the world (accounting for around half UK trade), whereas in our view the UK would move to free trade vis-à-vis all countries. Certainly that is the policy we propose on 'Brexit'/'Breset' and so it should be costed accurately.

They assume that the EU would react by raising trade and regulative barriers against UK exporters even though we impose no such barriers on EU exporters to us; as discussed above, this is highly unlikely because EU industries are closely integrated in many cases with UK industry and the UK market. They would be damaged by difficulties in accessing UK input products and would fear retaliation by the UK to EU aggression. At the same time it is possible for UK exporters to have free access to the EU market without undermining the existing prices created by the customs union. While EU businesses would regret the loss of high preferential prices in the UK market, they would be against a vindictive response which would make matters worse for them.

A final concern is how accurate their model can be in assessing a major change in commercial relationships like leaving a customs union. The 'multilateral gravity model' they use, due to Costinot and RodriguezClare (2013) (CR), assesses all countries' bilateral trade according to calculated bilateral elasticities which effectively 'sum up' the total ('general equilibrium') effects of the change. Thus CR argue that, if one is prepared to assume some set of 'micro-foundations' (that is, underlying relationships between consumers and producers, such as the state of competition), one can regard the gravity model as an accurate method to evaluate any shock to trade. At a theoretical level one can accept that, given a constant elasticity of trade response, an estimate of the effects of a tariff shock would be accurate. However, the question is whether one can regard such an elasticity as 'structural', that is invariant to the type of policy shock created. We discuss this in more detail in Chapter 4 . The basic point is a simple one: an elasticity sums up the effect of a tariff on trade via many different 
channels, some of which reinforce each other, some of which offset each other. These channels will be activated to different degrees by different shocks. Therefore an elasticity that works when only one thing is disturbed, namely the product tariff, will differ when that disturbance is accompanied by many changes to other tariffs. In the case of a large shock to the structure of trade such as leaving a customs union, the elasticity will no doubt be quite different again. As CR point out, the difficulty lies in assessing the elasticities to use, and what we would add is that they are likely to vary with the nature of the joint shock imposed on the economy, and the effects of this on ambient features of the economy such as consumer prices, wages, and supplies of capital and of different types of labour.

Our model here, based on four sectors and four major 'countries' can reasonably be criticized as too aggregative to provide highly accurate estimates, yet it does have an explicit theoretical defence of the way it computes the equilibrium structure of industry and consumption; it at least is for sure a structural general equilibrium model, which can in principle evaluate any shock to the structure of trade or the economy. The gravity model may work well numerically, and be more accurate in detail, for quite general changes in conditions, like a general drop in transport costs, mirroring globalization, which is what CR use it for. The problem with using it for a shock to trade structure like the UK leaving a customs union is that the responses will certainly not be the same as for a general globalization shock; indeed such a shock changes the UK's internal structure substantially, in a way not assumed in a gravity model.

A further argument of Ottaviano et al. is that there would be 'dynamic' effects of leaving the EU, from reduced investment, technological diffusion, export learning effects, and investment in R\&D. However, all these effects assume that there is no expansion in similar opposite effects as trade expands with the rest of the world. We see here again the omission of the general ROW effects of leaving a customs union. It must also be stressed that estimating these effects is difficult and uncertain; the empirical literature on growth is marked by much elaborate theory but considerable problems in 'identifying' the effects of growth mechanisms in practice.

Probably the most important element for the UK is the extent to which the UK state can establish favourable tax and regulation conditions for competition and entrepreneurship; because of this, in leaving the EU we avoid many damaging features of EU intervention and this will be beneficial, regardless of the structure of trade. Here recent work (Minford, 2015) has shown strong evidence that barriers to business affect UK growth. This is identified in Table 1.1 showing costs as a factor that could lower UK growth by some 0.5 per cent per annum, as a result of the 
dynamic effects on entrepreneurship of excessive regulation, especially in the labour market.

It is also said that we would no longer influence EU regulations, which is true. But we do not influence the regulations of any country to which we export and yet our exports are made to conform to them; this is part of our export costs, and our influence in the EU has little if any impact on these costs. But by leaving we avoid the massive cost of these regulations to our own production in general, as shown in Table 1.1. What will happen when we leave is that our exporters will have to continue to observe EU regulations on their products as they do now and as they do for all other countries to which they export; this is simply a normal cost of exporting anywhere. Also under the new suggested UK-EU treaty they could agree to continue to implement these regulations on all their production. As for everyone else (over 90 per cent of GDP) EU regulations will cease to be relevant, lifting both a current burden and a future threat.

It is true that the EU restrains UK politicians from self-damaging acts, such as subsidizing particular industries. However, politicians of most parties are now generally aware of the costs of such measures; and also the World Trade Organization (WTO) has become more effective in discouraging them. But in any case the costs of such particular actions are relatively minor.

Thus the costs to the UK of being in the EU, already high, are likely to increase under the pressure of the euro crisis. This implies that the case for leaving the EU will become even stronger, to the point where it overcomes the inertial force of the status quo. There is now definitely to be a referendum on whether to remain in the EU on whatever renegotiated terms this government is able to achieve. As can be seen from the figures above, the most desirable option is a new treaty with the EU that largely withdraws from EU joint arrangements but collaborates on particular issues of common interest, such as rights of migration, free capital movements, and possibly trade agreements on particular industries like cars where there is large-scale cross-investment. Of course political cooperation will continue in areas of mutual interest as with all our allies.

\section{THE BOTTOM LINE: WHAT SHOULD BRITAIN DO IN THE LIGHT OF THESE COSTS?}

When a country changes its institutions, as we are discussing here, we are in effect comparing outcomes over two contrasting long-term futures. The future of the UK in or out of the EU therefore involves two main sets of unknowns: 
(1) How would UK policies evolve outside the EU and how would they evolve inside?

(2) What are the effects of these policy differences on UK performance?

To determine (1) we need to judge what UK policy would be outside the EU and what EU policy (as a key constraint on UK policy if it remained inside) would also be.

To determine (2) we need reliable models of policy effects.

Clearly both these requirements are hard to meet with any certainty. The resulting uncertainty has led some people to argue that the decision must be made on other, largely political grounds - that economics cannot in practice contribute to the debate.

Yet this is a non sequitur. For example in taking personal decisions about future careers we may lack any certainty about how each will turn out in terms of income, yet we do not as a result decide purely on grounds of our enjoyment of each career.

In the rest of this book we make assumptions about EU policies based on what they have been until now and also on the basis of statements of intent by the majority of EU governments, such as that of 'ever-closer union'. Faced with the crisis of the euro, euro-zone governments have made it clear that they will do 'whatever it takes' to maintain the euro in all participating countries; as the crisis has subsided they have committed themselves to much closer fiscal and banking union, as part of the overall agenda of ever-closer union. Some economists on this side of the Channel have been inclined to downplay this commitment and suggest that there would be, for example, a euro break-up, but there is every reason to believe that the statements represent real policy intentions, given that they have been systematically carried out so far.

We make assumptions about UK policies on similar grounds. UK political experience since 1979 has produced a broad consensus about the need for market-based policies; even the banking crisis has not in practice much disturbed this consensus, in spite of the fact that at one stage Labour under Ed Miliband seemed to wish to move away from it. This is not to say that UK policy follows some pure 'free market' model; like any country leaning more towards market-based policies, it has always had a fair amount of intervention and regulation moderating pure free market outcomes - as has the US also, to take another prominent example of a country that clearly leans towards free market solutions.

Perhaps the overriding consideration when one contemplates the different policies that could emerge from the EU versus those emerging from the UK on its own, is that the political economy of the two entities differs markedly. In the UK all of the policy agenda is under ongoing 
challenge, and the demands of vested interests for special treatment are closely scrutinized by a public process of evaluation and debate. In the EU, policy is made by a small elite, subject to little debate, and vested interest demands are often met behind closed doors, with little scrutiny by some open democratic debate. The European Parliament, which is supposed to be the equivalent of our national Parliament in creating effective scrutiny and debate, is a weak institution with little power and dominated itself by groups of MEPs whose interests do not lie in opposing vested interest demands (often the contrary), who back the elite-led process of the EU and who have neither the resources, the energy nor the inclination to hold the executive to account. Fundamentally it is this weakness in political economy that makes us expect a poor policy outcome from Brussels compared with Westminster.

These assumptions cover the most likely policy outcomes. Of course they may be wrong, and we can consider how we might insure against this happening. In practice, if they do turn out to be wrong, there are responses that would largely deal with the effects of a worsening if we were not in the EU, but these are to a high degree absent if we remain inside. UK institutions could change again, but EU institutions generally cannot be assumed to respond well, if at all. This embeds a further layer of argument about political economy: that just as the EU has relatively poor institutions for dealing with competing economic demands, so it has relatively inflexible institutions for dealing with changes in the economic environment.

What then of the models used to evaluate the effects? We have used models that are standard in international trade evaluations for the trade calculations and models of the economy that have been developed by ourselves and others for evaluating distortions to labour and product markets. The calculations they produce must be regarded as orders of magnitude designed to indicate a balance of advantage in each area and whether it is large or trivial.

Certain features of our results stand out. First, it is quite against the UK's interests to join the euro; as it happens, the UK negotiated an optout from the euro but since 'ever-closer union' includes being part of the euro, one can expect endless pressure to abandon this opt-out should we remain in the EU. Second, the UK would be better off with free trade, unbound by the EU's customs union policies. Third, it would be better off without EU regulation of the labour market and with its own regulations of product markets, especially those in finance.

To these economic findings that we contribute we can add some related points that are already well understood. First, control of immigration requires control of EU immigration, contrary to the EU stipulation of free movement. Second, the UK is not in favour of 'ever-closer union', the 
accepted description of the EU's long-term mission; not being in the euro, it will not participate in the proposed banking and fiscal union and it has not accepted the 'legal union' currently under discussion in the EU. Third, the City's ability to compete in world financial markets is a paramount UK interest best served by a UK-designed regulatory structure.

It seems rather obvious that there is no possible revision of the EU Treaties that could accommodate these UK interests. These treaties are designed for all members and they cannot be changed to allow one member to operate by different rules. In effect even a friendly government head such as Angela Merkel has made it quite clear that there is a strict limit on what treaty change is possible. One could summarize it this way: the UK would have allies for 'reforms' of EU practices (that is, movements towards more free trade and competition within the EU, such as liberalizing the service markets) but removal of the powers to regulate UK labour and product markets, to set customs union tariff and non-tariff barriers, and to enforce free movement are simply not negotiable, nor is the general objective of ever-closer union, including the joining of the euro.

At the same time one can find many areas of economic activity where the UK and the EU have common interests that could be well served by a variety of cooperative agreements. 'Leaving the EU' does not mean having nothing to do with the EU. Indeed it has been pointed out in his Financial Times articles by Wolfgang Munchau that the UK has effectively already left the EU in the practical sense that it is not in, nor has any intention of joining, the euro and has refused to subscribe to the longer-term aims of union. Nevertheless the UK does have a relationship with the EU. The question is how it can be modified in the best interests of both sides.

We can approach this question by thinking of a procedure under which, on a designated day, the UK leaves the EU formally at 9 am and then by $6 \mathrm{pm}$ of the same day proclaims a plan to negotiate a fresh set of relationships with the EU that respect the UK interests set out above but that also provide for cooperation in areas of mutual advantage. Whether this would constitute some sort of 'membership' of the EU is a matter of semantics; it would be a new treaty relationship of the UK as a self-governing country with the EU as a group of close allies, quite different from the 'membership' relationship set out under the current general treaties and yet comparable with it in being a 'positive relationship' involving cooperation and mutual burdens in a wide variety of policy areas. Indeed, shorn of the endless recrimination and doubt that now encrusts our existing relationship with the EU, it could lead to much more proactive dialogue and to many more joint actions.

This new relationship should not be confused with some aggressive act. Existing members of the EU are highly conscious of the awkwardness for 
their own development, complete with the euro, of having the UK as a member that does not sign up to much of the core agenda, including the euro itself. What is required is a rewriting of the relationship so that this awkwardness is removed on both sides, leaving in its place a treaty of cooperation that brings definite gains to both sides.

Plainly in non-economic areas such as defence and foreign policy, cooperation already occurs outside the EU treaties through NATO, general diplomatic activity and legal agreements, such as on extradition. It is in the economic area where the EU has taken overriding powers that the UK wishes to remove and replace with selective cooperation. This embraces trade, regulation and immigration.

\section{Trade}

On trade the UK's interest is in free trade with the rest of the world and, if possible, with the EU. Because the WTO has been halted in its extension of general free trade by the failure of the Doha Round, some observers fear that by leaving the EU trade collective the UK would lay itself open to hostile commercial policy from the rest of the world and from the EU.

Yet the first point is that by removing the tariff and non-tariff barriers erected by the EU on its behalf, the UK would at once benefit from a large fall in import prices, a direct and obvious benefit to consumer living standards; we estimate this at around 10 per cent. The size of this effect may come as a shock given that there is much discussion of the EU single market's effects in promoting competition. However, what is not so widely recognized is the role of tariff and non-tariff barriers in raising the costs of imports and so reducing the spur of competition from abroad. According to our estimates the EU's tariff-equivalent of all protectionist measures is around 16 per cent.

The second point is that the UK would, on leaving, find that the prices at which it sold to other countries would be world prices. These are the prices that products obtain when sold to a randomly chosen country, taking as given existing commercial policies of the countries of the world. These policies affect the relative domestic prices of different products (that is, inside each country) and together with the GDP of each country determine total world demand for each product type; world demand and supply for that product type determines its world price. If the UK makes a product of that type, this will be the price it gets.

How do these prices differ from those that UK producers get inside the EU? For what they sell outside the EU there is no difference. But for what they sell inside the EU they get more, because of the protection created by 
the EU customs union. They lose this 'customs union premium' and this of course makes such UK producers oppose leaving the EU.

Hence we see the gainers from leaving are the consumers and firms who can buy at world prices, while the losers are the firms who gain from this premium, which they will now lose. Naturally therefore one should expect a strong campaign by these losing firms against leaving the EU. Yet the arithmetic of gains and losses overall is plain. Besides consumers, our gainer firms that inside the EU face higher prices on imports and on import-type and export-type home products, spend much more on them than our loser firms produce of them, even though these gainers tend not to realize this since it is a matter of obscure economics. On top of this net gain to our consumers and firms, there is the gain from moving resources away from industries in which we are inefficient to those where we are efficient and moving consumption to goods that are cheaper (but currently made expensive by protection). It is this calculation that underlies our finding in Chapter 4 that leaving the EU would bring a trade gain of around 4 per cent of GDP.

At this point people often express concerns. Will not non-EU countries erect barriers against our goods? Will we not face a barrier to selling in the EU?

What we need to understand is that if some other countries set up barriers against our trade, unlikely as that is, this would have no implications for the world prices of the types of products we produce. Those prices are set in all the markets of the world. If our producers faced some extra tariffs in some markets, this would have no effect on the world price of the goods we produce. The UK produces a small fraction of world exports in virtually all product markets. These UK exports will be more expensive in the markets with extra tariffs but the impact on the overall demand for these products will be negligible. Then what will happen to our exports in the markets where they face these tariffs? They will be diverted to markets where they do not. In the markets where we face tariffs, our competitors will sell the goods we did not sell; we will sell more in their other markets.

Given that world prices will be unaffected, our calculation holds exactly. This calculation estimates the gains of moving from protected EU prices on imports and exports to world prices on these.

This is not an easy idea to grasp for those not used to international trade theory. Most people think in terms of 'market access' and the bilateral bargaining between producers and the country to which they are selling. But this is not how world trade works - except in the very short run, which is soon over and so not relevant to a long-term shift like leaving the EU.

Consider a simple example: Jaguar cars. These have a certain price around the world as a brand of luxury car, competing closely with other 
luxury brands such as BMW, Mercedes, Porsche and Lexus. There is a world price of such luxury cars, by which we mean that Jaguar has to price its product competitively with all these other prices; world demand from upper middle class people around the world drives all these prices to the level at which this demand is equal to the world supply of these products. Now suppose that when the UK leaves the EU, say Thailand imposes a higher tariff on Jaguars. This would simply raise the Thai price; Jaguars will not sell less around the world nor would their price fall because any reduction of sales to Thailand would be easily absorbed by slightly higher sales in each of the many other markets where Jaguars are sold.

This illustrates what is known in international trade theory as the 'importance of being unimportant'; a small supplier in world markets such as the UK, faced with a tariff from country X, would simply divert supply to another market and so keep its price unchanged, passing the tariff on to the consumers in country X. The UK is too small to affect the world price of any product it sells - hence it is 'unimportant' at the world level.

This powerful argument implies that the calculation of the UK's net trade gains is immune to what third countries decide to do with their trade barriers on UK products, and is explicitly based on the assumption that the EU indeed raises its usual ('most favoured nation', MFN) trade barriers on UK products so that UK export prices in the EU market revert to world prices.

Let us consider further the question of what third country behaviour will actually be: of course few, if any, will raise tariffs against the UK. There are three main reasons why countries raise tariffs or non-tariff barriers. The first is to drive down the border prices of imports by reducing home demand; this is known as the 'optimal tariff' policy of using trade policy to improve the terms of trade. But as we have seen, no country has any 'monopoly power' over UK goods - that is, no ability to drive down UK prices - as the UK would simply divert them elsewhere at the same price.

The second reason countries raise tariffs is for the raising of revenue, especially in developing countries with low tax-raising capacity. But our leaving the EU has no effect on their desire to do this.

The third reason is the lobbying of home industries requiring protection, often on 'infant industry' grounds. But again the UK's relationship to the EU does not change this.

Some people are concerned that if we leave the EU we will be unable to influence the big trade agreement negotiations between the EU and the US or China. However, it is not at all clear that we want to be involved in such negotiations. Our aim is to sell the products we have at world prices wherever there is demand. These negotiations may raise or lower the world prices of our exports or those of our imports. But the outcome will be 
determined by the interests of many other countries; it is unclear how we could push them towards raising the prices of our exports and lowering the prices of our imports. Our diplomatic efforts are better spent on issues where we can have a useful effect.

By implication we have no particular interest in signing Free Trade Agreements with individual countries - even with China, which, as it happens, is much wedded to the idea of the WTO as a supranational keeper of trade peace. Like China, we too would have a strong interest in the WTO's role in this respect. We note in later chapters of this book how world trade has grown rapidly in spite of there being no Doha Round. It seems that multinational companies (MNCs) have created tariff competition much as they have created tax competition between different countries eager to obtain their investment in industry. Tariff competition works by the MNC offering to invest in industry at stage $\mathrm{X}$ of value-added in a country provided that country does not levy tariffs on its inputs or interfere with its exports. Stage X could be assembly; then the inputs could come from cheaper parts of the world, while the good assembled is exported all over the world. In effect this means that any tariff on imports of the assembled good into this country will have no effect on prices in the country because these are set by export prices in world markets - any rise in prices of the imported product would lead to them being undercut by exporters shifting product to the home market. By this method the MNC will have caused tariffs to be effectively extinguished on this industry in this country. Something like this must be happening for us to witness the massive growth of industrial intra-trade all over the Far East, for example. Even in the EU and the US we see that protection has been coming down steadily over the past few decades - similar forces are eroding protection there.

It is sometimes said that we should try to obtain a Free Trade Agreement with the EU. The problem about this is that with free trade the UK would enjoy lower prices on goods that are protected in the EU. If they levy on us the usual EU tariff-equivalent, then prices of UK exports to the EU would be brought up to EU levels and so the protection to EU producers would not be undermined. Hence it is natural to make the assumption that the EU levies its usual (MFN) tariff-equivalents on us when we leave. If we ask it not to, then in effect it seems we are asking to remain inside the customs union and are not leaving at all! However, in free trade agreements such as the North American Free Trade Agreement (NAFTA), different countries can have zero tariffs against their countries even while enjoying zero tariffs from other FTA partners; it may well be possible for the UK to negotiate such arrangements for particular industries that are highly integrated across the EU. 
For example there are some industries where competition is heavily restricted, such as aerospace and airlines. In these examples existing markets are heavily organized between the UK, EU and other producers. In effect leaving the EU would leave these arrangements intact.

An example of a highly integrated industry is the volume car industry in which multinational companies have invested heavily on the assumption of a protected EU market. For such cases the drop in world prices would lead to heavy losses. An arrangement whereby the UK and the EU maintained zero tariffs and tariff-equivalents against each other would make much sense for this industry; effectively the EU market would maintain its existing prices and UK producers would continue to sell into this EU market at these prices, even though UK prices for cars would fall to world levels so that EU producers would lose their EU price premium in the UK market.

Failing that, given that the UK encouraged these investments, it could reasonably make some compensation when policy changes, on the usual basis that reform requires losers to be, if possible, compensated by gainers (in this case taxpaying households who enjoy lower consumer prices and other firms that enjoy lower input prices).

Alternatively, the existing arrangements for this industry could be left in place for a transitional period of a decade, allowing the industry time to adjust its capital stock and strategies to the new reality. This would mean that for a decade the current EU customs union protection would be continued by the UK for this industry only. The gain to the economy of this part of the trade regime change would be deferred for this decade, but then would be reaped like all the rest.

The first key point that emerges from this long discussion of trade is that, if we were outside the EU, the most important feature of UK traded output, whether exports or home products competing with imports, would be its 'competitiveness', that is, its 'value for money' as a product. If it were value for money, it would be bought all around the world and would displace foreign competition in the home market, whatever other countries may do in their trade policies.

The second key point is that certain industries will be worse off when EU protection is removed and they will lobby for transitional remedies, as well as for staying in the EU. In the well-worn way that accompanies supply-side reform they will have to be helped over the transition. But their opposition and transitional pain should not obscure the gains to the economy overall from lower prices of traded goods generally as we leave the EU and return to free world trade. 


\section{Regulation}

Those defending EU regulations often argue that we are the cause of our own excess regulation because we 'gold-plate' EU regulations. Thus really, they argue, we cause the regulation and if we left the EU we would not change it, since we created it.

However, this is to misunderstand why we 'gold-plate' EU regulation. If there was no EU directive we would not have the regulation at all. But EU directives are fairly vague and imprecise. Our common law is, by contrast, extremely concrete and precise because it is derived from many cases of past law. Current application has to be argued from these precedents. Our statute law introduces new criteria into the law and so to operate alongside common law it has to generate equivalent precision, otherwise it cannot be used effectively in UK courts which will not rule on the basis of unclear and vague pronouncements. Thus our civil service lawyers have to take EU directives and turn them into precise and workable law; this involves carefully going through all the contingencies in which they might apply and saying what exactly they mandate. None of this is necessary on the continent where only statute law prevails and is interpreted by judges with wide powers.

Unfortunately this EU-directive-created law introduces much extra complexity into our law. This would not be there without EU directives.

Evaluating all this EU regulation is a huge task and our approach has been to take the salient interventions that distort markets. These are mainly interventions in the labour market, inspired by 'social' and 'human rights' considerations. In product markets the situation is complex. In some markets EU regulation may not be notably different from regulations thrown up by domestic regulators; furthermore the EU is pro-competitive in its policy philosophy, as can be seen in the Competition Directorate. But there is still a general problem with having regulation coordinated by a central EU authority: it creates intense lobbying by the firms in each industry and tends to favour dominant producers who can lobby most effectively. A recent example is vacuum cleaners, where James Dyson has protested against the large German industry's success in setting a high ceiling on vacuum cleaners' energy consumption; according to Dyson this is anti-competitive, favouring the dominant German industry against newer competitors. There is also the salient case of financial markets in which EU regulators are distrustful of major competitive processes, there is populist dislike of financiers, and most EU countries have industries with poor ability to compete against the City of London and hence propose measures that would reduce its competitive edge. The latest proposal for a Financial Transactions Tax has emerged out of such factors. 
The difficulty in costing these regulative interventions in labour and product markets is to know how in practice they will be applied, by regulators and by the courts. However, in essence all these interventions constitute a tax on business activity financing a transfer to some beneficiary, a particular class of worker or a particular class of consumer. This tax in turn reduces economic activity and employment (if it does not reduce the number of people wanting to work it will increase unemployment; but often when employment falls the relevant job-losers leave the labour market). It does so by raising the country's relative costs in world markets or 'competitiveness' because the tax cannot be shifted back onto labour or other inputs by lowering wage and other input prices; the reason is that unemployment benefits and minimum wages prevent wages from falling while other input prices are generally set in world markets.

The models we have used here only cost the one-off effect on activity and so on. However, there may also be an effect on growth itself, which therefore causes an accumulating loss of activity and employment; this effect persists as long as the tax remains. This 'dynamic' effect is now the focus of policy interest and we have used a new model developed by Minford (2015) to contribute a tentative estimate of this effect too.

Estimating the effects of regulation is made difficult by the need to calculate the 'tax-equivalent' of the regulation: namely what cost it imposes on the businesses regulated and how the 'revenue', or gains, from the regulation are distributed. If the gains are distributed in a 'lump sum' manner so that there are no incentive effects on recipients' behaviour, then we can disregard the latter. But the costs on business will almost certainly affect business incentives; calculating them requires a substantial amount of research on the details of the businesses involved. In the case of regulation of labour markets, again, it is a matter of calculating how they affect business incentives, but in this case there will also be key incentive effects on workers.

In two major product areas the impact of EU regulation either has been or threatens to be massive: energy and finance. In energy the EU is mandating extremely high targets for 'renewable' energy such as from wind and sun; here the costs have been large and well-known (Congdon, 2014a). In finance the UK has now ceded final regulative authority to the EU; given the EU majority countries' hostility to financial activity for the reasons mentioned above, we have considerable reason to fear substantial negative effects from their future policies (Congdon, 2014b).

In labour markets the EU's interventions have been going on for a long time, ever since the era of Jacques Delors and the inauguration of the 'Social Market'. The UK insisted on an opt-out from the Social Chapter but, having signed up to the Single Market, it was forced to limit 
working hours on the grounds that this was a 'health and safety' matter coming within the scope of Single Market rules. Then when Labour came into power in 1997, it soon surrendered the opt-out from the Social Chapter, ushering in many more EU labour market interventions, including 'TUPE' (giving unions protection of their previous arrangements under privatization), maternity and paternity rights, contract rights, and rights for part-timers.

In our evaluation of the effects of all these measures, we have used the Liverpool Model, which was one of the first UK models to have a 'supply side' built to assess them. The fact that the range of estimates is wide is inevitable, given the difficulty of assessing exactly how much all these tax-equivalents are. The general point is that the EU is a highly interventionist organization, with a strong bias in favour of 'top-down' regulation and a mind-set that is 'socialist' in the sense that it favours action to force what it sees as direct gains for classes of people regardless of their market consequences. This philosophy is not necessarily accompanied by demands for public ownership and the opposition to private business or to privatization that is associated with explicit socialism, though it is in the cases of some politicians; it is usually described as 'social democracy', but unfortunately its economic effects are still damaging.

\section{Immigration}

The fury of a wide swathe of UK voters with the loss of control of immigration is a major new element in the UK debate since this book's first edition. It is a major game-changer, since while voters have some understanding of economic costs, they tend to relegate them in importance as irritants that can be absorbed rather than as being allowed to cause major institutional changes.

Leaving the EU would enable the UK government to apply the same criteria to EU immigrants as they do to non-EU immigrants. This does not mean there would necessarily be fewer immigrants overall; rather it would imply that an economic test would be applied to all immigrants and the balance of immigration altered towards immigrants with defined and required skills and with defined familial links to existing UK citizens.

This rebalancing of immigrants away from the unskilled would defuse the fury of voters referred to above. This fury has built up because unskilled immigrants have had damaging effects on poor, unskilled UK citizens; essentially these people's jobs and communities have been greatly affected, even if nationally UK employment has gone up to absorb the immigration and for other people these immigrants have brought advantages (for example in supplying low-wage services cheaply). 
We have not allowed for this rebalancing of immigration to cause any economic cost or benefit. Arguably it should cause a benefit since the immigrants would become more skilled and this could create greater spillover effects for UK citizens. However, we have not attempted to quantify this. What is clear is that it totally contravenes the EU freedom of movement of peoples and is incompatible with EU membership; it cannot be an object of 'negotiation'. This EU freedom may or may not be necessary for the EU's economic objectives, but it is certainly central to the political definition of the EU as a process of ever-closer union, to a federal state to which, of course, free movement is integral.

It must be stressed that this creation of controls on all immigration would not be a policy to 'stop immigration from the EU'. Rather it would subject all immigration to the same criteria, on which the UK has traditionally - at least until the recent fury created by inability to control EU migration - been rather liberal in its approach. Many people of UK origin and with UK associations exist all around the world and many have been admitted to the UK, notably from old colonies such as East Africa or Hong Kong. UK business and universities have also in practice been largely free to recruit the highly skilled labour they needed. Nor has this ever been controversial. What did become controversial was massive immigration from the poorer countries of the EU in the last decade and a half; this, together with some cases of false asylum often involved with terrorism, has soured UK public opinion on immigration, to the point where it is not possible to see any remedy except the imposition of controls on EU labour.

\section{POLICY CONCLUSIONS}

In the first edition of this book it was possible to argue that there was some room for doubt about the desirability of the UK leaving the EU. Maybe the EU would improve or maybe UK policies would deteriorate so that the long-term balance of advantage could swing back to remaining.

This is no longer possible, in the light of two main factors. First, the EU's approach to economics has decidedly worsened and is continuing to do so under the impact of the euro crisis, which rumbles on unstoppably. The second factor is the emergent political hostility to the key economic interest of the UK in its large financial sector. As we can now see, these poor economic policies follow essentially from the poor political economy of the EU, dominated as it is by vested interests.

Allowing for these factors in our calculations makes it impossible to suggest any doubt that economically the UK would enjoy greatly improved 
prospects outside the EU. As we have already noted, many of the fears expressed about trade or business are the result either of misunderstanding or of pure self-interest on the part of those benefiting from EU protectionism or other interventionist measures.

Unfortunately such economic arguments on their own do not carry much weight with a general public suspicious of abstract argument. However, the politics of the EU question have now been changed by the rise of the immigration issue on the back of unfettered entry from the EU by migrants from poorer countries. While the well-to-do may sneer that such an issue does not reflect the overall net benefits of poor immigrants, it does reflect the anxieties of many poorer UK citizens who feel the direct impact of these arrivals on their jobs, communities and public goods. In practice the only way to resolve this issue is to rebalance EU immigration towards the more skilled and to restore control of total EU immigration to the UK government - this cannot be done without leaving the EU.

So it turns out that just as the EU's economic policies have become most threatening to UK interests, political developments from EU migration have made it likely that the UK would decide in a referendum to leave the EU. The politics and economics may well have converged.

\section{WHAT IS IN THE REST OF THIS BOOK}

The remaining chapters of this book divide into two main parts. The next three chapters consider in detail the costs and benefits of the key aspects of remaining in the EU: regulation, joining the euro, and trade. They provide the analytic and empirical back-up for the costs set out in this opening chapter. The next part consists of the final three chapters, which provide a detailed account of the facts and the associated literature on trade, respectively in agriculture, manufacturing and services. These chapters provide the background for our overall evaluation of the trade costs in Chapter 4; they can be read separately, as Chapter 4 sums up the findings from them that are relevant to the cost-benefit calculation it makes.

All views expressed in this book are personal to the authors and are in no way related to those of the organizations they are affiliated to. 